\title{
ANALISIS PENGARUH CORPORATE GOVERNANCE DAN UKURAN PERUSAHAAN TERHADAP MANAJEMEN RISIKO PADA PERUSAHAAN DI BURSA EFEK INDONESIA
}

\author{
Arina Juwita* dan Teddy Jurnali* \\ *Program Studi Akuntansi, Fakultas Ekonomi \\ Universitas Internasional Batam \\ Email: arina.juwita@uib.edu; teddy@uib.ac.id
}

\begin{abstract}
This investigation means to break down the impact of corporate governance, and company size, on risk management in companies recorded on the Indonesia Stock Exchange. Risk management which is a dummy variable estimated through the presence of a risk management committee will be given an estimation of 1 and in the event that it doesn't have an estimation of 0 . The independent variable used is corporate governance by using the proxy proportion of independent directors, board size, audit quality, company size and ownership institutional. This examination utilizes secondary data types, and the total population is 563 companies found on the Indonesia Stock Exchange in 2015 to 2017, where the example was chosen utilizing the purposive sampling method. Logistic regression analysis is a statistical method that will be used in this test. The consequences of this investigation clarify that audit quality has a significant negative effect, institutional ownership and firm size have a significant positive effect on risk management. The proportion of independent directors and the size of the board of commissioners do not affect risk.
\end{abstract}

\section{PENDAHULUAN}

Pertumbuhan ekonomi Indonesia mengalami kenaikan pada tahun 2018 sebesar $5.17 \%$ jika dibandingkan dengan tahun 2017 yang hanya sebesar 5.07\% disebabkan oleh tingginya pertumbuhan investasi fisik dan pertumbuhan konsumsi masyarakat (KEMENPERIN, 2019). Globalisasi dan perkembangan teknologi dalam transaksi bisnis tidak hanya menjadikan situasi seperti keuntungan namun juga harus diwaspadai. Era ini merupakan masa yang sangat mudah berubah sehingga membuat perusahaan menghadapi tantangan yang kompleks dalam mengembangan perusahaan. Membuat semua resiko ini harus diukur dan dikelola secara efektif oleh perusahaan. Menurut Meizaroh dan Lucyanda (2011) pengenalan manajemen risiko terstruktur secara resmi sangat penting bagi perusahaan. Namun, masih banyak pihak manajemen perusahaan memandang sebelah mata untuk manajemen risiko yang menurut sebagian pihak hanya sebagai penghindaran dan menghilangkan risiko yang dapat terjadi pada perusahaan, padahal pengelolaan manajemen risiko yang baik dapat mengurangi dan menghindari risiko sebelum risiko tersebut terjadi. Suatu perusahaan untuk dapat menyeimbangkan biaya dan keuntungan, perusahaan dapat memanfaatkan manajemen risiko yang bisa menjamin perusahaan dan bertanggung jawab akan risiko yang akan dihadapi (Krus \& Orowitz , 2009). Manajemen mempunyai peran penting untuk dapat menyeimbangkan kedua hal tersebut untuk kelangsungan hidup perusahaan. Menerapkan manajemen risiko yang efektif (Enterprise Risk Management) akan menjadi motivasi baru bagi manajemen Situasi ekonomi Indonesia saat ini, sedang menghadapi persoalan yang cukup sulit dan tidak bisa ditebak, baik dari sisi internal bahkan eksternal. Perekonomian global yang saat ini dipaksakan adalah dampak kenaikan ekonomi global yang tidak merata. Bias yang berpotensi turun ini didorong oleh perkiraan pertumbuhan ekonomi AS.

Beberapa perusahaan besar di luar negeri maupun di Indonesia banyak menghadapi masalah keuangan baik dari pelaporan keuangan bahkan ada yang 
mengalami kebangkrutan, ini menunjukkan penerapan ERM belum efektif diterapkan oleh perusahaan. Di Indonesia, kegagalan perusahaan pada krisis moneter tahun 2008, merupakan lembaran hitam bagi perusahaan karena harus memilih mengganti pemilik, mengatur alur keuangan perusahaan bahkan kebangkrutan menyebabkan beberapa perusahaan besar yang harus melewati proses pemulihan keuangan, berganti pemilik bahkan kepailitan. Menerapkan konsep corporate governance pada perusahaan, transparasi tata kelola perusahaan akan banyak menguntungkan berbagai pihak seiring dengan pertumbuhan ekonomi yang semakin berkembang (Nasution \& Setiawan, 2007). Solusi untuk mengembalikan kepercayaan publik salah satunya dengan menerapkan manajemen risiko yang baik yang juga disertai tata kelola perusahaan.

Kewajiban perusahaan pada jaman sekarang adalah menerapkan manajemen risiko dan corporate governance dimulai dengan pengamatan, indentifikasi, antisipasi hingga meminimalisir risiko. Tingkat risiko juga berhubungan dengan rendahnya komitmen manajemen dalam menerapkan prinsip good corporate governance.

Penerapan manajemen risiko juga mendorong terciptanya good corporate governance karena manajemen risiko merupakan salah satu jembatan untuk menyinergikan pihak dalam dan eksternal perusahaan, ditambah lagi peran corporate governance dan audit internal yang berperan penting dalam suatu perusahaan sering terabaikan dalam penerapan manajemen risiko. Kesalahan mendasar bergantung pada data masa lalu, dengan fokus pada risiko yang kecil dan mengabaikan risiko yang lebih besar maupun risiko yang tersembunyi dan gagal mengelola risiko secara bersamaan. Meskipun manajemen risiko memiliki perhatian yang lebih meningkat, namun riset akademik dibidang ini masih sedikit yang diketahui. Pengelolaan manajemen risiko yang baik dapat meningkatkan kemakmuran pemegang saham dan pihak-pihak terkait serta berperan dalam kelangsungan hidup perusahaan. Pada saat yang bersamaan, kebutuhan untuk memperkuat praktik manajemen risiko telah menjadi salah satu pelajaran utama dari krisis keuangan. Meskipun hal ini disadari dengan baik oleh perusahaan, tetapi masih sedikit perusahaan yang memperhatikan manajemen risiko

\section{KAJIAN LITERATUR \\ PENGEMBANGAN HIPOTESIS}

DAN

Manajemen risiko merupakan unsur terpenting dalam mewujudkan good corporate governance didalam suatu perusahaan, karena saat penerapan manajemen risiko membaik, perusahaan akan menambah kontrol risiko pada core competence dan competitive advantage (Drew \& Kendrick, 2005). Berikut penjelasan pengaruh corporate governance terhadap manajemen risiko.

\section{Proporsi Dewan Komisaris}

Komisaris independen artinya dewan komisaris yang berasal dari luar emitmen atau perusahaan publik dan mencapai persyaratan untuk menjadi komisaris independen yang mensyaratkan tidak boleh memiliki hubungan dengan perusahaan, anggota direksi atau pemegang saham primer dan tidak memiliki kepentingan serta saham pada perusahaan tersebut (Peraturan Otoritas Jasa Keuangan No 33, 2014). Dewan komisaris memiliki komposisi proporsi komisaris independen yang tinggi akan sangat efektif dalam pemantauan karena mereka merupakan independent dari manajemen dan akan tertarik untuk melindungi reputasi mereka sehingga dewan komisaris independen akan membantu perusahaan untuk menghindari kerugian dan melindungi citra perusahaan (Pathan, 2009).

Neifar dan Jarbui (2017), Raymond (2016), Badriyah et al., (2015), Ahmad et al. (2015), Subramaniam et al. (2015), Wardhana (2013), Oliveira et al. (2011), Desender (2009), Beasley et al, (2005) menyatakan bahwa proporsi komisaris independen berdampak signifikan positif terhadap manajemen risiko. Hasil penelitian yang sama ditunjukkan oleh Arifina (2017), 
Sari (2013), Agustina (2014), Jatiningrum dan Fauzi (2012), Golshan et al. (2012), Husaini (2013) dan Desender (2007).

H1: Proporsi komisaris independen memiliki pengaruh terhadap manajemen risiko

\section{Ukuran Dewan Komisaris}

Dewan komisaris berfungsi melaksanakan pengawasan serta bertanggung jawab atas peninjauan terhadap kebijakan manejemen, alur pengelolaan pada umumnya, tentang emitmen maupun perusahaan publik serta memberi petuah kepada direksi (Peraturan Otoritas Jasa Keuangan No 33, 2014).

Dewan komisaris harus memperhatikan jumlah dari anggota dewan komisaris untuk melaksanakan tugasnya secara efektif karena makin banyak anggota membuat kekuasaan yang lebih dalam pengendalian karena memiliki kekuatan dalam fungsi pengawasan karena terdapat sumber daya yang besar (Subramaniam et al., 2009), sehingga diharapkan dapat bertukar keahlian, pikiran, informasi dan lebih mudah dalam mengawasi kebijakan dan laporan serta mendorong untuk penerapan manajemen risiko dan menentukan keberadaan komite manajemen risiko.

Arifina (2017), Mokhtar \& Mellet (2014), Raymond (2016), Husaini (2013), dan Jatiningrum \& Fauzi (2012) menyatakan ukuran dewan komisaris berdampak positif terhadap manajemen risiko. Sedangkan Agustina (2014), Febryna (2015), Ravana et al., (2014), Elzahar dan Hussainey (2012), Donnelly dan Mulcahy (2008), Bassett et al., (2007), Cheng dan Courtenay (2006) membuktikan bahwa variabel ini tidak berdampak terhadap manajemen risiko.

$\mathrm{H} 2$ : Ukuran dewan komisaris memiliki pengaruh terhadap manajemen risiko

\section{Kualitas Komite Audit}

Mekanisme good corporate governance memiliki salah satu unsur yang penting yaitu komite audit. Penyusunan laporan keuangan haruslah memiliki kredibilitas yang tinggi sehingga dapat menjadi alat untuk mengawasi operasional perusahaan juga merupakan peran penting komite audit. Kualitas audit yang terdiri dari bebas, memiliki pengetahuan dan pengalaman ilmu akuntansi dan keuangan serta cerdas sehingga tugas dalam pengawasan dapat berjalan dengan baik dan adil (Husaini, 2013). Adanya desakan yang cukup banyak agar membuat suatu komite manajemen risiko. Komite manajemen risiko dilihat sebagai bantuan dan nilai lebih saat auditor melakukan memonitoring risiko internal, sehingga auditor akan memutuskan untuk mengurangi kerugian reputasi dan tidak berhasilnya audit (Subramaniam et a., 2009).

Sanusi et al. (2017), Mockhtar \& Mellet (2014), Agustina (2014), Sari (2013), Husaini (2013), Syifa (2013), Putri (2013), Wardhana (2013), Golshan et al. (2012), Jatiningrum dan Fauzi (2012), Oliveira et al (2011), Desender (2009) menunjukkan bahwa tahap implementasi manajemen risiko secara positif dipengaruhi oleh kualitas komite audit. Sedangkan Raymond (2016), Sulityaningsih dan Gunawan (2016), Febryna (2015) yang menyatakan bahwa kualitas komite audit tidak berdampak terhadap manajemen risiko.

H3: Kualitas komite audit memiliki pengaruh terhadap manajemen risiko

\section{Kepemilikan Institusional}

Menurut Tarjo (2008), kepemilikan jumlah saham perusahaan yang dimiliki oleh instansi keuangan maupun instusi lain disebut sebagai kepemilikan institusional. Kepemilikan institusional mempunyai makna yang utama untuk mengawasi manajemen dan menganjurkan penguatan dalam hal pengamatan yang maksimal.

Saat ini external stakeholder seperti kepemilikan institusional akan meminta informasi tentang risiko yang dilakukan perusahaan. Investor institusional mempunyai kesanggupan lebih besar untuk mengendalikan kebijakan manajemen risiko perusahaan (Liebienberg et al., 2003). Tekanan dari pada pemangku kepentingan ini akan menjadi lebih intens ketika mereka akan menyetujui rencana modal untuk 
pengalokasian modal, mengembangkan strategi bisnis dan dalam menetapkan toleransi risiko perusahaan sehingga perusahaan akan cenderung untuk membuat komite manajemen risiko untuk mengatasi risiko kedepannya. Hal ini membuat perusahaan yang dipegang lebih oleh kepemilikan institusional cenderung memberikan infomasi secara sukarela dalam laporan tahunan mereka dan memastikan mereka bertindak demi kepentingan pemegang saham (Ghazali \& Weetman, 2006). Sanusi et al., (2017) Hoyt et al. (2006) menemukan bahwa kepemilikan institusional berpengaruh terhadap manajemen risiko. Sedangkan Golshan et al. (2012), Kristiono dan Al Azhar, et al. (2014), Fathimiyah (2012), Siswanto (2013), Rizki (2013) Oliveira et al. (2011) menyatakan kepemilikan institusional tidak memiliki pengaruh terhadap manajemen risiko.

H4: Kepemilikan instititusional memiliki pengaruh terhadap manajemen risiko

\section{Ukuran Perusahaan}

Ukuran perusahaan diukur melalui jumlah asetnya. Dalam hal aset, perusahaan skala besar memiliki jumlah aset yang juga besar. Hal ini menggambarkan dalam pendanaan, perusahaan besar memiliki lebih banyak akses untuk menyediakan pendaaan melalui pasar modal. Kecendurangan untuk menggunakan dana eksternal juga akan meningkat seiring dengan meningkatkan ukuran perusahaan (Mirawati, 2014).

Perusahaan yang memiliki ukuran yang besar juga mengarah untuk menerapkan praktek tata kelola lebih tepat dibandingkan perusahaan dengan ukuran kecil disebabkan kian besar perusahaan akan kian besar pula resiko yang akan dijalani. Hal ini berhubungan dengan tingginya tangungjawab perusahan kepada para pemegang saham karena mempunyai saham yang lebih banyak. Konsekuensinya perusahaan yang lebih besar lebih memungkinkan untuk membentuk komite manajemen risiko guna melewati risiko yang ada (Badriyah et al., 2015).

Febryna (2015), Kristiono dan Al Azhar et al. (2014), Mokhtar dan Mellett
(2013), Wardhana (2013), Syifa (2013), Sari (2013), Anisa (2012), Oliveira et al., (2011), Pendapat Beastly et al., (2005) ukuran perusahaan memiliki pengaruh positif terhadap manajemen risiko. Sebaliknya, Sulistyaningsih dan Gunawan (2016), Agustina (2014), Arifina (2017) dan Mubarok (2013) menyatakan ukuran perusahaan tidak memiliki pengaruh terhadap manajemen risiko.

H5: Ukuran perusahaan memiliki pengaruh terhadap manajemen risiko

\section{METODE PENELITIAN}

Analisi regresi logistik merupakan metode analisis yang akan diterapkan pada penelitian ini, dikarenakan variabel dependennya berskala nominal (dummy variable). Data sekunder merupakan data dipakai untuk penelitian yang didapat peneliti secara indirect atau menggunakan media perantara (Indriantoro \& Supomo, 2009). Peneliti menggunakan laporan keuangan tahunan perusahaan yang terdaftar di Bursa Efek Indonesia dari tahun 2015 sampai 2017. Sampel pada perusahaan harus memiliki laporan keuangan yang telah diaudit serta menggunakan mata uang rupiah yang diterbitkan oleh Bursa Efek Indonesia, serta data yang lengkap dan tidak melakukan delisting dari tahun 2015 hingga 2017 .

\section{Variabel Dependen}

Desender (2009) dan Liebenberg \& Hoyt (2003) menggunakan adanya komite manajemen risiko pada suatu perusahaan sebagai proksi manajemen risiko. Pengukuran variabel ini adalah bila perusahaan ada komite manajemen risiko lalu akan diberikan nilai 1. Apabila perusahaan tidak ada komite manajemen risiko lalu diberi nilai 0 .

\section{Variabel Independen}

Variabel independent yang digunakan dalam penelitian ini yaitu:

1. Proporsi Komisaris Independen

Menurut Husain (2013) dalam meningkatkan kualitas pengawasan diperlukannya kehadiran dewan komisaris independen karena tidak mempunyai afiliasi 
pada perusahaan maka dapat mengambil langkah secara bebas dan tidak terikat. Proporsi komisaris independen mempunyai pengaruh terhadap tingkat perhatian risiko yang akan dihadapi perusahaan karena bertanggungjawab dalam melakukan pengawasan atas penerapan tata kelola perusahaan. Menurut Husain (2013), Jamei (2017), Desender (2009) dan proporsi komisaris independen dapat dihitung sebagai berikut:

$$
\text { PKI }=\frac{\text { Jumlah Komisaris Independen }}{\text { Jumlah Keseluruhan Dewan Komisaris }}
$$

\section{Ukuran Dewan Komisaris}

Memastikan perusahaan menerapkan manajemen risiko yang efetif merupakan salah satu peran dewan komisaris. Menurut Desender (2007) besarnya ukuran dewan komisaris dapat menguatkan kualitas penerapan manajemen risiko dengan adanya pertukaran informasi dan keahlian satu sama lain. Pengukuran ukuran dewan komisaris bisa dihitung dengan besarnya total anggota yang terdapat pada dewan komisaris pada perusahaan (Husain, 2013).

\section{Kualitas Audit}

Memelihara kredibilitas pada setiap proses pembuatan laporan keuangan dan pengawasan terhadap kebijakan perusahaan merupakan tugas dari komite audit (Rachmawati, 2017). Menurut Husain (2013) karakteristik komite audit dapat dihitung dengan melihat reputasi audit yang digunakan suatu perusahaan. Perusahaan yang memakai
Kantor Akuntan Publik yang termasuk dalam KAP Big Four akan diberikan nilai 1, namun jika memakai jasa auditor eksternal selain KAP Big Four lalu akan diberikan nilai 0.

\section{Kepemilikan Institusional}

Kepemilikan jumlah saham perusahaan oleh instansi seperti perusahaan perusahaan reksa dana, perusahaan dana pensiun, perusahaan investasi, perusahaan asuransi disebut kepemilikan institusional (Bernandhi, 2013).

Upaya pengamatan yang sangat ketat oleh kelompok pemodal instansi dibutuhkan jika tingkat kepemilikan institusional yang tinggi guna menghalangi perilaku kecurangan. Rumus untuk mengukur kepemilkan institusional:

$$
\mathrm{KI}=\frac{\text { Jumlah Saham Institusional }}{\text { Total Saham Beredar }}
$$

\section{Ukuran Perusahaan}

Klasifikasi besar atau kecilnya perusahaan bisa dibagi dengan ukuran perusahaan. Perusahaan yang lebih besar lebih cenderung menerapkan konsep manajemen risiko terpadu daripada perusahaan yang lebih kecil. Menurut Golshlan \& Rasid (2013) mengukur ukuran perusahaan adalah Natural Logaritma terhadap total aset perusahaan.

Ukuran perusahaan

$$
=\operatorname{Ln}(\text { Total Asset) }
$$

\section{HASIL PENELITIAN \\ Statistik Deskriptif}

Tabel 1

Hasil Uji Statistik Deskriptif Variabel Penelitian

\begin{tabular}{|l|c|c|c|c|}
\hline \multirow{2}{*}{\multicolumn{2}{c|}{ Variabel }} & \multicolumn{4}{c|}{ Statistik Deskriptif } \\
\cline { 2 - 5 } & Minimum & Maksimum & Rata-Rata & Std. Deviasi \\
\hline Proporsi komisaris independen & 0.25 & 0.50 & 0.39 & 0.0791 \\
\hline Ukuran dewan komisaris & 2.00 & 7.00 & 3.77 & 1.389 \\
\hline Kepemilikan institusional & 0.00 & 1.00 & 0.5497 & 0.2879 \\
\hline Ukuran perusahaan (Jutaan) & 28,864 & $61,433,000$ & $18,585,233$, & $23,865,320$, \\
\hline N (Jumlah data) & 932 & & & \\
\hline
\end{tabular}

Sumber: Data sekunder diolah (2019) 
Hasil uji statistik menunjukkan pada tabel 1 rata-rata komposisi komisaris independen bernilai 0.39 atau $39 \%$. Berdasarkan peraturan OJK 33/POJK.04/2014 paling sedikit perusahaan mempunyai $30 \%$ dari total keseluruhan komisaris. Berdasarkan uji statistik deskriptif ini menerangkan bahwa syarat yang tertera dalam peraturan Otoritas Jasa Keuangan telah dipenuhi oleh perusahaan di Indonesia.

Variabel ukuran dewan komisaris memiliki nilai minimum 2 dan nilai maksimum 7 dengan rata-rata 4 anggota. Berdasarkan peraturan OJK nomor 33/POJK.04/2014 jumlah dewan komisaris yang wajib dimiliki oleh perusahaan adalah 2 orang. Hal ini menunjukkan bahwa syarat yang tertera dalam peraturan Otoritas Jasa Keuangan telah dipenuhi oleh perusahaan di Indonesia.
Variabel ukuran perusahaan mempunyai total aset rata-rata $\mathrm{Rp}$ $18,585,233,847,639$. Berdasarkan peraturan yang terdapat pada Badan Pengawas Pasar Modal XI/PM/1997 setidaknya total asset perusahaan melebihi 100 Milyar akan tergolong kedalam perusahaan besar. Maknanya bahwa rata-rata perusahaan yang tercatat pada Bursa Efek Indonesia merupakan perusahaan yang digolongkan ukuran besar yang mempunyai total asset melebihi dari 100 Milyar.

Hasil uji statistik deskriptif pada tabel 1, kepemilikan institusional memiliki ratarata nilai sebesar $54.97 \%$ yang menunjukkan mayoritas saham perusahaan yang tercatat di Bursa Efek Indonesia dimiliki setengahnya oleh institusi.

\section{Tabel 2}

Hasil Uji Statistik Deskriptif Variabel Dummy

\begin{tabular}{|l|l|l|l|}
\hline Variabel & Kategori & Frekuensi & Persentase \\
\hline Kualitas audit & $0=$ Non Big 4 & 664 & $71.2 \%$ \\
& $1=$ Big 4 & 268 & $28.8 \%$ \\
\hline
\end{tabular}

Sumber: Data sekunder diolah, 2019.

Pada Tabel 2 menjelaskan frekuensi big four mengaudit perusahaan sebesar $28.8 \%$ atau setara 268 sampel data dari jumlah data pengujian. Hasil penelitian juga menunjukkan bahwa 664 sampel data atau sebesar 71.2\% diaudit oleh Kantor Akuntan Publik yang bukan anggota dari KAP big four.

Tabel 3

Hasil Uji Statistik Deskriptif Variabel dependen

\begin{tabular}{|l|l|l|l|}
\hline Variabel & Kategori & Frekuensi & Persentase \\
\hline Manajemen risiko & $\begin{array}{l}\text { 0= Tidak memiliki Komite manajemen } \\
\text { risiko } \\
1=\text { Memiliki komite manajemen risiko }\end{array}$ & 622 & $66.7 \%$ \\
\hline
\end{tabular}

Sumber: Data sekunder diolah, 2019.

Pada hasil pengujian statistik komite manajemen risiko lebih besar yaitu menunjukkan perusahaan yang terdapat $66.7 \%$. Menunjukkan kesadaran perusahaan komite manajemen risiko sebesar 33.3\%. masih kurang akan pentingnya manajemen Sedangkan perusahaan yang belum memiliki risiko dalam suatu perusahaan. 


\section{Uji Multikoliniearitas}

Tabel 4

Hasil Uji Multikoliniearitas

\begin{tabular}{|l|c|c|}
\hline \multirow{2}{*}{\multicolumn{1}{c|}{ Variabel }} & \multicolumn{2}{|c|}{ Collinearity Statistics } \\
\cline { 2 - 3 } & Tolerance & VIF \\
\hline Proporsi komisaris independen & 0.976 & 1.025 \\
\hline Kualitas komite audit & 0.796 & 1.256 \\
\hline Ukuran dewan komisaris & 0.789 & 1.267 \\
\hline Ukuran perusahaan & 0.710 & 1.409 \\
\hline Kepemilikan institusional & 0.983 & 1.018 \\
\hline
\end{tabular}

Sumber: Data sekunder diolah (2019).

Pada Tabel 4, dapat dilihat bahwa nilai VIF kurang dari 10 , hal ini berarti

model penelitian ini tidak ada multikolonieritas antar variabel.

\section{Analisis Regresi Logistik}

Uji hipotesis ini diterapkan untuk Goodness of Fit Test, uji t dan uji R square melihat hasil uji Hosmer and Lemeshow's (Nagelkerke R Square).

\section{Uji Hosmer and Lemeshow's Goodness of Fit Test}

\section{Tabel 5}

Hasil Uji Hosmer and Lemeshow

\begin{tabular}{|l|l|}
\hline Effect Test & Sig. \\
\hline Hosmer and Lemeshow & 0.237 \\
\hline
\end{tabular}

Sumber: Data sekunder diolah (2019).

Tabel di atas memperlihatkan nilai yang dihasilkan adalah 0.237 yang berarti > 0.05 . Hasil ini menerangkan tidak terdapat perbedaan signifikan antara model dengan nilai observasinya, dan model regresi ini dianggap tepat dan dapat dipakai untuk pengujian selanjutnya

\section{Uji $t$}

Tabel 6

Hasil Uji $t$

\begin{tabular}{|l|l|l|l|}
\hline Variabel & Koefisien & Prob. & Kesimpulan \\
\hline Kontanta & -12.805 & 0.000 & \\
\hline Proporsi komisaris independen & -1.216 & 0.212 & Tidak signifikan \\
\hline Ukuran dewan komisaris & 0.014 & 0.813 & Tidak signifikan \\
\hline Kualitas audit & -0.612 & 0.000 & Signifikan negatif \\
\hline Ukuran perusahan & 0.438 & 0.000 & Signifikan positif \\
\hline Kepemilikan institusional & 0.745 & 0.008 & Signifikan positif \\
\hline
\end{tabular}

Sumber: Data sekunder diolah (2019).

a. Proporsi Komisaris Independen Terhadap Manajemen Risiko (H1)

Berdasarkan Tabel 6, hasil penelitian menerangkan bahwa proporsi komisaris independen tidak memiliki pengaruh pada manajemen risiko yang menunjukkan bahwa adanya komisaris independen hanya sebatas untuk memenuhi kriteria dari good corporate governance tetapi tidak cukup berperan dalam peningkatan manajemen risiko pada perusahaan (Meizaroh, 2011). Keberadaan komisaris independent tidak banyak mendorong perusahaan untuk membuat komite manajemen risiko, karena dapat dilihat dari masih sedikit perusahan yang mempunyai komite manajemen risiko di Indonesia. 
Hasil penelitian yang sama juga ditunjukkan oleh Sanusi, et al., (2017), Arfina (2017), Al-Maghzom et al. (2016), Lofti and Malgharni (2013), Sari (2013), Agustina (2014), Jatiningrum \& Fauzi (2012), Golshan et al., (2012), Husaini (2013), Meizaroh (2011) dan Desender (2007) yang menyatakan komisaris independen tidak berpengaruh terhadap manajemen risiko.

b. Ukuran Dewan Komisaris Terhadap Manajemen Risiko (H2)

Hasil penelitian menunjukkan bahwa ukuran dewan komisaris tidak memiliki pengaruh terhadap manajemen risiko yang disebabkan oleh keahlian dewan komisaris yang sudah berpengalaman sehingga lebih efektif dan detail dalam memperhatikan risiko yang ada di perusahaan dan merasa tidak memerlukan komite manajemen risiko dalam mengelola risiko yang ada di perusahaan. Hasil penelitian ini konsisten dengan peneliti sebelumnya Tai et al. (2018), Agustina (2014), Febryna (2015), Ravana et al. (2014), Elzahar \& Hussainey (2012), Donnelly \& Mulcahy (2008), Bessett et al. (2007), Cheng \& Courtenay (2006).

\section{c. Kualitas Komite Audit Terhadap Manajemen Risiko (H3)}

Hasil penelitian menunjukkan negatif terhadap manajemen risiko. KAP Big four telah mempunyai popularitas yang sangat baik dalam menyajikan kualitas audit bagi perusahaan, dampaknya perusahaan yang menggunakan KAP Big Four cenderung tidak membuat komite manajemen risiko disebabkan auditor eksternal tersebut merasa sudah bisa menangani risiko yang ada pada perusahaan. Hal tersebut konsisten dengan hasil penelitan Sanusi et al (2017), Mockhtar \& Mellet (2014), Agustina (2014), Sari (2013), Husaini (2013), Syifa (2013), Putri (2013), Wardhana (2013), Golshan et al (2012), Jatiningrum dan Fauzi (2012),
Oliveira et al (2011), Desender (2009), Lopes \& Rodrigues (2007).

d. Kepemilikan Instititusional Terhadap Manajemen Risiko (H4)

Hasil penelitian menunjukkan signifikan positif terhadap manajemen risiko. Hal ini menunjukkan besarnya kepemilikan institusional berdampak pada manajemen risiko perusahaan dan mengurangi konflik keagenan. Kepemilikan institusional dianggap mampu memainkan peran dalam memantau sehingga akan menganjurkan perusahaan untuk bisa memberikan informasi tambahan secara sukarela, salah satunya dengan cara membentuk komite manajemen risiko. Hasil tersebut konsisten dengan penelitian sebelumnya yaitu sejalan dengan penelitian sebelumnya Hoyt et al (2006), Sanusi et al (2017).

\section{e. Ukuran Perusahaan Terhadap Manajemen Risiko (H5) \\ Hasil penelitian menerangkan} pengaruh signifikan positif terhadap manajemen risiko. Jenis ukuran perusahaan baik besar maupun kecil diharapkan bisa mengidentifikasikan muslihat maupun risiko yang mungkin bisa berlangsung pada perusahaan. Perusahaan yang tergolong ukuran besar akan menerapkan tata kelola yang ketat dibandingkan perusahaan yang tergolong ukuran kecil, hal ini akan membuat perusahaan yang tergolong ukuran besar akan menganggap manajemen risiko ialah hal yang utama untuk diperhatikan sehingga akan mengarahkan perusahaan agar membuat komite manajemen risiko sebagai daya tarik juga bagi investor. Hasil penelitian sejalan dengan penelitian Dupire dan Slagmulder (2017), Febryna (2015), Kristiono dan Al Azhar et al. (2014), Mokhtar dan Mellett (2013), Wardhana (2013), Syifa (2013), Oliveira et al. (2011), Subramaniam et al. (2009), Beastly et al. (2005). 


\section{Uji Koefisien Determinasi (Nagelkerke R Square)}

\section{Tabel 7}

Hasil Uji Koefisien Determinasi (Nagelkerke R Square)

\begin{tabular}{|l|l|l|}
\hline Variabel dependen & NagelkerkeR Square & Cox \& Snell R Square \\
\hline Manajemen Risiko & 0.203 & 0.146 \\
\hline
\end{tabular}

Sumber: Data sekunder diolah (2019).

Pada regresi ini, nilai nagelkerke $R$ square adalah 0.203. Hal ini menerangkan variabel independen proporsi komisaris independen, ukuran dewan komisaris, kualitas audit, kepemilikan institusional,

\section{KESIMPULAN}

Tujuan penelitian ini adalah menganalisis faktor yang mempengaruhi manajemen risiko. Proporsi komisaris independen, ukuran dewan komisaris, kualitas audit, kepemilikan institusional dan ukuran perusahaan merupakan variabel independen pada penelitian ini. Berdasarkan hasil pengujian dan pembahasan, maka dapat disimpulkan bahwa,

Proporsi komisaris independen tidak memiliki pengaruh terhadap manajemen risiko. Hal ini dikarenakan adanya komisaris independen hanya untuk memenuhi peraturan untuk good corporate governance dan sehingga kemungkinan adanya manajemen risiko pada perusahaan masih kecil.

Ukuran dewan komisaris tidak memiliki pengaruh terhadap manajemen risiko. Hal ini mungkin disebabkan dewan komisaris yang sudah memiliki pengalaman, sehingga dewan komisaris merasa cukup untuk melakukan pengawasan dan tidak membutuhkan komite manajemen risiko sebagai bentuk dalam mengawasi dan mengelola risiko yang ada.

Kualitas audit memiliki pengaruh signifikan negatif terhadap manajemen

\section{Keterbatasan}

Penelitian ini memiliki beberapa keterbatasan yaitu penelitian ini menunjukkan bahwa faktor-faktor yang digunakan belum dapat membuktikan secara jelas tentang faktor yang mempengaruhi ukuran perusahaan, manajemen risiko mampu menerangkan variabel manajemen risiko sebesar $20 \%$, dan sebesar $80 \%$ dapat dijelaskan oleh faktor lain di luar model yang tidak digunakan pada penelitian ini.

risiko. Hal ini menunjukkan bahwa KAP Big four memiliki reputasi yang baik dalam mengevaluasi perusahaan, sehingga merasa tidak membutuhkan komite manajemen risiko untuk membantu mengelola risiko yang terdapat pada perusahaan.

Kepemilikan institusional memiliki pengaruh signifikan positif terhadap manajemen risiko. Hal ini menunjukkan bahwa kepemilikan insitusional yang besar akan mendorong untuk lebih memperhatikan manajemen risiko dalam pengambilan keputusan perusahaan agar tidak terjadi penyimpangan pada manajemen dan bisa mengelola risiko dengan tepat.

Ukuran perusahaan memiliki pengaruh signifikan positif terhadap manajemen risiko. Perusahaan dengan ukuran yang besar akan menganggap manajemen risiko adalah hal yang sangat penting dan merupakan daya tarik bagi para investor, sehingga kian besar ukuran suatu perusahaan akan lebih perhatian terhadap manajemen risiko, dan mengarahkan untuk membentuk komite manajemen risiko.

manajemen risiko. Nilai variabel manajemen risiko yang di ukur menggunakan variabel dummy dianggap kurang mewakili penerapan manajemen risiko. 


\section{Rekomendasi}

Berikut rekomendasi yang bisa di sampaikan untuk penelitian selanjutnya adalah Pengukuran manajemen risiko bisa menggunakan cara lain seperti ERM Frame work by COSO, dan menambah variabel independen yang berbeda sebagai tambahan namun sudah dijelaskan di model penelitian

\section{Implikasi Manajerial}

Manajemen risiko merupakan hal yang perlu diperhatikan pada jaman sekarang dimana ekonomi yang mudah berubah-rubah. Manajemen risiko dapat menghasilkan value added untuk perusahaan dan merupakan bagian dalam proses pengambilan keputusan. Penelitian ini menerangkan bahwa perusahaan yang memiliki komite manajemen risiko masih sangat rendah. Masih rendahnya kesadaran perusahaan untuk membuat komite khusus untuk menangani risiko yang ada, padahal dengan manajemen risiko dapat menghindari kerugian yang sangat besar karena penanganan yang lebih baik atas tugas-tugas berisiko. Ketika manajemen risiko meresapi seluruh perusahaan, maka dapat mendorong manajemen lebih waspada setiap pengambilan keputusan.

Peran dari tata kelola perusahaan juga sangat utama dalam penentu manajemen risiko pada perusahaan. Komposisi komisaris independen ialah bagian yang penting agar membantu perusahaan menerapkan manajemen risiko. Sebaiknya perusahaan harus lebih memperhatikan jumlah dan latar belakang dalam menentukan komisaris independen, karena komisaris independen akan mengevaluasi perusahaan dan kebijakan perusahaan sehingga bisa mengurangi konflik keagenan pada perusahaan serta sadar akan pentingnya pengelolaan manajemen risiko yang baik.

Penetapan jumlah dari dewan komisaris bagi perusahaan harus lebih diperhatikan dari segi latar belakang dan pengalaman, sehingga dewan komisaris akan mendorong perusahaan menerapkan manajemen risiko dengann membentuk
Subramaniam et al. (2015) seperti leverage, jenis industri dan account receivable .

Pada penelitian ini menggunakan data sekunder, diharapkan pada penelitian selanjutnya memakai data primer dengan survey kuesioner atau wawancara mendalam agar memberikan wawasan yang lebih bermakna terhadap temuan-temuan baru.

komite manajemen risiko agar bisa mengatasi risiko yang mungkin dihadapi kedepannya agar perusahaan bisa bertahan dengan kondisi yang tidak menentu.

Kualitas audit memiliki pengaruh signifikan negatif terhadap manajemen risiko. Perusahaan yang memakai jasa audit Big Four memiliki lebih banyak keahlian dalam membantu perusahaan untuk menerapkan manajemen risiko. Hal ini sangat menguntungkan pihak perusahaan karena Big Four mengambil tindakan yang diperlukan dengan memastikan kualitas tertinggi pelaporan keuangan sesuai dengan peraturan dan standard, namun lebih baik perusahaan juga membentuk komite manajemen risiko sebagai bentuk pengelolaan risiko perusahaan, sehingga tidak bergantung pada pihak eksternal dalam mengawasi dan mengelola risiko.

Hasil penelitian menerangkan kepemilikan institusional memiliki pengaruh signifikan positif terhadap manajemen risiko. Tingkat kepemilikan institusional dapat akan meningkatkan pengawasan terhadap kebijkan-kebijakan dan laporan yang diberikan perusahaan serta pengelolaan risiko. Sebaiknya perusahaan mempertahankan komposisi kepemilikan institusional yang cukup besar karena pihak tersebut akan lebih memperhatikan dalam pengelolaan risiko dan mendorong membuat komite manajemen risiko. Namun, perusahaan yang memiliki kepemilkan institusional yang rendah juga harus menyadari pentingnya membuat komite manajemen risiko sebagai bentuk pencegahan risiko yang akan tejadi. 
Hasil penelitian menerangkan ukuran perusahaan memiliki pengaruh signifikan positif terhadap manajemen risiko. Kian besar ukuran suatu perusahaan, akan semakin besar pula asset yang dimiliki perusahaan akan membuat perusahan besar tersebut harus lebih ketat dalam mengelola risiko yang ada, karena semakin banyak asset yang dimiliki maka lebih banyak pula risiko yang akan dijalani kemudian. Seharusnya perusahaan yang memiliki ukuran perusahaan yang besar mampu mempertahankan perhatiannya tehadap risiko yang ada sehingga perusahaan terdorong untuk mengimplementasikan tatakelola yang tepat dengan membentuk komite manajemen risiko. Perusahaan besar maupun kecil sebaiknya melihat manajemen risiko sebagai daya tarik bagi para investor dan juga akan

\section{DAFTAR PUSTAKA}

Agustina, C. H. (2014). Pengaruh Kompetisi, Corporate Governance, Struktur Kepemilikan Terhadap Pengungkapan Risiko. Diponegoro Journal of Accounting, Vol. 3 (4), 1-13.

Ahmad, R. A., Abdullah, N., Jamel, N. S., \& Omar , N. (2015). Board Characteristics and Risk Management and Internal Control Disclosure Level: Evidence from Malaysia. Procedia Economics and Finance. 31, 601-610.

Akbar, S., Kharabsheh, B., Hughes, J. P., \& Ali Shah, S. Z. (2017). Board structure and corporate risk taking in the UK financial sector. International Review of Financial Analysis, Pages 101-110.

Arifina, Yessi. (2017). Peran Tata Kelola Perusahaan dan Risiko Pelaporan Keuangan dalam Pembentukan Komite Manajemen Risiko yang Terpisah. Jurnal Akuntansi Bisnis, Vol. XVI (1).

Badriyah, N., Sari, R. N., \& Basri, Y. M. (2015). The Effect of Corporate Governance and Fim Characteristics on Fim Performance and Risk Management as an Invertening Variable. Procedia Economic and Finance, 31, 868-875.

Bernandhi, Riza (2013). Pengaruh Kepemilikan Manajerial, Kepemilikan membantu perusahan untuk bisa bertahan dengan kondisi yang tidak menentu.

Secara keseluruhan corporate governance ialah salah satu elemen utama dalam peningkatan efisiensi ekonomi dan kelangsungan perusahaan dalam pengelolaan risiko. Tata kelola yang tepat dan menerapkan prinsip tata kelola perusahaan yaitu transparasi, akuntabilitas, tanggung jawab dan independensi akan menimbulkan manajemen risiko yang baik pula. Keterkaitan ini akan memberikan landasan yang kuat dan tidak terpisahkan dari pelaksanaan tata kelola perusahaan terutama pengelolaan manajemen risiko sehingga dapat menjadi sarana dalam mewujudkan tujuan perusahaan atas keberhasilan usaha yang tidak tergantikan, manajemen yang efektif dan kelangsungan perusahaan.

Institusional, Kebijakan Deviden, Leverage dan Ukuran Perusahaan terhadap Nilai Perusahaan. Semarang: Universitas Diponegoro.

Beasley, M. S., Clune, R., \& Hermanson, D. R. (2005). Enterprise risk management: An empirical analysis of factors associated with the extent of implementation. Journal of Accounting and Public Policy, 24(6), 521-531. http://doi.org/10.1016/j.jaccpubpol.2005. 10.001

Bassett, M., Koh, Ping-Sheng, \& Tutticci, I. (2007). The Association between employee stock option disclosures and corporate governance: Evidence from an enchanced disclosure regime. The British Accounting Review, Vol. 39(4), 303-322.

Cheng E. C. M. \& Courtenay S. M. (2006). Board Composition, Regulatory Regime and Voluntary Disclosure. The International Journal fo Accounting, 41 (3), 262-289.

COSO (Committee of Sponsoring Organizations of the Treadway Commission) (2009). Effective Enterprise Risk Oversight: The Role of Board of Directors. (www.coso.org). 
Desender, K. (2007). On the Determinants of Enterprise Risk Management Implementation. Managing Worldwide Operations \& Communications with Information Technology, 115.

Desender, K., \& Lafuente, E. (2009). The Influence of Board Composition, Audit Fees and Ownership Concentration on Enterprise Risk Management. SSRN Electronic Journal.

Drew, S. A., \& Kendrick, T. (2005). Risk Management: The Five Pillars of Corporate Governance. Journal of General Management , 31 (2), 19 36.

Donnelly, R., \& Mulcahy M. (2008). Ownership and Voluntary Disclosure in Ireland.

Corporate Governance: An

International Review, 16, pp. 416-429.

Dupire, M., \& Slagmulder, R. (2017). Risk

Governance of Financial Institutions: The Effect

of Ownership Structure and Board Independence. Finace Research Letter, Vol. 28, 227 - 237.

Elzahar, H. \& Hussainey, K. (2012).

Determinants of narrative risk disclosures in UK Interim

Reports. Journal of Risk Finance,

Vol. 13(2), 133-147.

Fathimiyah, Venny. (2012). Pengaruh

Struktur Kepemilikan Terhadap Risk

Management

Disclosure (Studi Survei Industri

Perbankan yang Listing di BEI tahun 2008-2010). Symposium Nasional Akuntansi XV.

Febryna, Desi (2015). Pengaruh Karakteristik Dewan Komisaris, Karakteristik Perusahaan dan Pengendalian Eksternal Terhadap Keberadaan Risk Management Committee. Jurnal Akuntansi Bisnis. Vol. 13(26). ISSN: 2541-5204.

Firth, M. and O.M. Rui. 2007. Voluntary Audit Committee Formation and Agency Costs. International Journal of Accounting, Auditing and Performance Evaluation, 4 (2), 142-160

Ghozali, I. (2001). Aplikasi analisis multivariate dnegan program SPSS. Semarang: Badan Penerbit Universitas Diponegoro.

Golshan, N. M., \& Rasid, S. Z. (2012). Determinants of Enterprise Risk Management Adoption: An Empirical Analysisof Malaysian Public Listed Firms. World Academy of Science, Engineering and Technology, 62.

Huang, Y.S. \& Wang, C.-J., (2014). Corporate Governance and Risktaking of Chinese Firms: The Role of Board Size, International Review of Economics and Finance.

Husaini., Saiful., Fadli., \& Aisya S. (2013). Corporate Governance and Enterprise Risk Management: An Empirical Evidence from The Unique Two Tier Boards System of Indonesia Public Listed Companies. Proceedings of World Business and Social Science Research Conference.

Indriantoro, Nur \& Supomo, Bambang. (2009). Metodologi Penelitian Bisnis untuk Akuntansi dan Manajemen Edisi Pertama. Yogyakarta: BPFE

Jamei, R. (2017). Tax Avoidance and Corporate Governance Mechanisms: Evidence from Tehran Stock Exchange. International Journal of Economics and Financial Issues, 638-644.

Jatiningrum \& Fauzi. (2012) Pengaruh Corporate Governance dan Konsentrasi Kepemilikan pada Pengungkapan Enterprise Risk Management.FEA Universitas Lampung.

Kementrian Perindustrian Republik Indonesia (2019). Analisis Perkembangan Industri. Edisi I.

Kleffner, A., Lee, R., \& McGannon, B. (2003). The Effect of Corporate Governance on The Use of Enterprise Risk Management Evidence from Canada. Risk Management and Insurance Review, 6(1), 53-73.

Komite Nasional Kebijakan Governance (KNKG). 2012. Pedoman Penerapan Manajemen Risiko Berbasis Governance. Jakarta: KNKG.

Kritiono, Zulbahridar \& AL Azhar. (2014). 
Pengaruh Struktur Kepemilikan Struktur Modal, dan Ukuran Perusahaan terhadap Risk Management Disclosure pada Perusahaan Perbankan yang Terdaftar di Bursa Efek Indonesia. JOM FEKON, Vol. 1 (2).

Krus, C.M., and H. L. Orowitz. 2009. The Risk-Adjusted Board : How Should The Board Manage Risk? Corporate Governance Advisor, 17(2), 1-6.

Liebenberg, A. P., \& Hoyt, R. E. (2003). The Determinants of Enterprise Risk Management: Evidence From the Appointment of Chief Risk Officers. Risk Management and Insurance Review, 6(1), 37-52.

Lofti, S., \& Malgharni, A. M (2014). The Relationship between Ownership Structure and Risk Management Evidence from Iran. International Journal of Academic Research in Business and Social Science, 4(2), 5362.

Lopes P. \& Rodrigues L. L. (2007). Accounting for Financial instruments: An Analysis of the determinants of disclosure in the Portuguese stock exchange. The International Journal of Accounting, Vol. 42(1), 25-56.

Maruhun, E. N. S., Abdullah, W. R. W., Atan, R., \& Yusuf, S. N. S. (2018). The Effects of Corporate Governance on Enterprise Risk Management: Evidence from Malaysian Shariah-Compliant Firms. International Journal of Academic Research in Business and Social Sciences, 8(1), 865-877.

Meizaroh \& Lucyanda, J. (2011). Pengaruh Corporate Governance dan Konsentrasi Kepemilikan pada Pengungkapan Enterprise Risk Management. Simposium Nasional Akuntansi, XIV. Aceh: Universitas Bakrie Jakarta, pp. 130.

Mirawati. (2014). Pengaruh Strukur Kepemilikan dan Ukuran Perusahaan terhadap Profitabilitas pada Perusahaan Property dan Real Estate yang terdaftar di Bursa Efek Indonesia. Fakultas Ekonomi, Universitas Maritim Raja Ali
Haji.

Mokhtar, E. S., \& Mellet, H. (2013). Competition, corporate governance, ownership structure and risk reporting . Managerial Auditing Journal, 28(9) .838 -865 .

Mubarok, M. A. (2013). Pengaruh Karakteristik Perusahaan dan Mekanisme Corporate Governance Terhadap Pengungkapan Risiko dala Laporan Keuangan Interim. Diponegoro Journal of Accounting.

Nasution, M., \& Setiawan, D. (2007).

Pengaruh Corporate Governance terhadap Manajemen di Industri Perbankan Indonesia. Simposium Nasional Akuntansi X, Makasasar, AKPM-05.

Neifar, Souhir, \& Jarboui, Anis. (2017). Corporate governance and operational risk voluntary disclosure: evidence from Islamic banks. Research in International Business and Finance. Vol. 46, 43-54.

Oliveira, J.S., L.L. Rodrigues, and R. Craig. 2011a. Risk-related disclosure practices in the annual reports of Portuguese credit institutions: an exploratory study. Journal of Banking Regulation, 12 (2), pp. $100-118$

Peraturan Otoritas Jasa Keuangan (2014), Direksi dan Dewan Komisaris Emiten atau Perusahaan Publik. Nomor: 33/PJOK.04/2014

Putri, E. E. (2013). Pengaruh Komisaris Independen, Komite Manajemen Risiko, Reputasi Auditor dan Konsentrasi Kepemilikan Terhadap Pengungkapan Enterprise Risk Management (Dimensi COSO Erm Framework). Universitas Islam Negeri Syarif Hidayatullah.

Rachmawati, I. A. Br. (2017). Pengaruh Dewan Direksi, Dewan Komisaris, Komite Audit dan Corporate Social Responsibility terhadap Kinerja Keuangan Perusahaan. Jurnal Akuntansi \& Ekonomi FE. UN PGRI Kediri Vol. 2 (2). ISSN: 2541-0180

Rasid, S. Z., Rahman, A. R., \& Ismail, W. K. (2011). Management accounting and risk management in Malaysian financial 
institutions An exploratory study.

Journal of Islamic Accounting and

Business Research, 2(2), 153-176.

Raymond, A. H. (2016). Analisis Pengaruh

Good Corporate Governance dan

Konsentrasi Kepemilikan terhadap

Pengungkapan Enterporse Risk

Management. Fakultas Ekonomika

dan Bisnis Universitas Diponegoro.

Riski, Afdal. (2013). Pengaruh Faktor-Faktor

Kepemilikan Manajemen, Kepemilikan

Institusi Domestik, Kepemilikan Institusi

Asing, Kepemilikan Publik dan Tingkat

Profitabilitas terhadap Risk Management

Disclosure. Fakultas Ekonomi

Universitas Bung Hatta.

Sanusi, Z. M., Nia, S. M., Roosle, A. N., Sari, R. N., \& Harjitok, A. (2017). Effects of Corporate Governance Structure on Enterprise Risk Management Practices in Malaysia. International Journal of Economics and Financial Issues, 7(1), 6-13.

Sari F, J. (2013). Implementasi Enterprise Risk Management pada Perusahaan Manufaktur Indonesia Lag. Accounting Analysis Journal. Vol. 2(2).

Siswanto, Ekiana. (2013). Pengaruh Struktur Kepemilikan dan Tingkat Profitabilitas terhadap Risk Managemetn Disclosure pada Perusahaan manufaktur. Fakultas Ekonomi Universitas Muhammadiyah Yogyakarta.

Subramaniam, N., \& Muttakin M. B (2015). Firm Ownership and board characteristics: Do they matter for corporate social responsibility disclosure of Indian Companies? Sustainability Accounting, Management and Policy Journal, 6(2), 138-165.

Subramaniam, N., L. McManus, and J.Zhang. (2009). Corporate Governance, Firm Characteristics, and Risk Management Committee Formation in Australia Companies. Managerial Auditing Journal, 24(4), 316-339.

Sulistyaningsih \& Gunawan, Barbara.
(2016). Analisis Faktor-Faktor yang Memengaruhi Risk Management Disclosure (Studi Empiris pada Perusahaan Manufaktur yang Terdaftar di Bursa Efek Indonesia Tahun 20122014. Journal UMS Vol.1(1).

Syifa, L. (2013). Determinan Pengungkapan Enterprise Risk Management pada Perusahaan Manufaktur di Indonesia. Accounting Analysis Journal. Vol.2(3), 286-294.

Tarjo. (2008). Pengaruh Konsentrasi Kepemilikan Institusional dan Leverage terhadap Manajemen Laba, Nilai Pemegang Saham serta Cost of Equity Capital. Simposium Nasional Akuntansi XI.

Tao, N. B., \& Hutchinson, M. (2013). Corporate governance and risk management: The role of risk management and compensation committees. Journal of Contemporary Accounting \& Economics, 9(1), 83-99.

V.W. Tai, Y-H. Lai, T-H. Yang, (2018) .The Role of the Board and the Audit Committee in Corporate Risk Management, North American Journal of Economics \& Finance.

Wardhana, A. A (2013). Pengaruh Karakteristik Perusahaan terhadap Tingkat Pengungkapan Risiko (Studi Empiris pada Perusahaan Non Keuangan yang Terdaftar di Bursa Efek Indonesia). Diponegoro Journal of Accounting Vol.2 (3), 1-14. ISSN 2337-3806.

$\mathrm{Wu}$, J., Wu, Z., (2013) Integrated risk management and product innovation in China: The moderating role of board of directors. Technovation, Vol. 34, 466476.

Y-L. Chen, Y-W. Chuang, H-G. Huang, J-Y. Shih. (2019) The Value of Implementing Enterprise Risk Management: Evidence from Taiwan's Financial Industry, North American Journal of Economics \& Finance 